\title{
CYBERBULLYING PENCEGAHAN DAN PENANGANAN PADA GURU BIMBINGAN KOUNSELING DI JAKARTA PUSAT
}

\author{
Ade Nursanti ${ }^{1)}$, Nuri Sadida ${ }^{2)}$, Riselligia Caninsti ${ }^{3)}$ \\ ade.nursanti@yarsi.ac.id ${ }^{1)}$, nuri.sadida@yarsi.ac.id ${ }^{2)}$, riselligia.caninsti@yarsi.ac.id ${ }^{3)}$ \\ Fakultas Psikologi Universitas YARSI ${ }^{1,2), 3)}$
}

\begin{abstract}
ABSTRAK
Cyberbullying adalah perilaku bullying yang terjadi didunia maya disampaikan melalui penggunaan media teknologi. Cyberbullying banyak dialami oleh siswa sekolah menengah pertama hingga sekolah menengah atas. Cyberbullying dapat terjadi dimanapun dan kapanpun, tidak selamanya terjadi disekolah. Dampak cyberbullying dapat mempengaruhi perilaku siswa disekolah. Diantaranya, menyebabkan siswa mengalami stress, depresi, merasa kesepian dan memiliki keinginan untuk bunuh diri. Besarnya dampak yang disebabkan oleh cyberbullying, menuntut berbagai elemen baik guru dan siswa untuk dapat mencegah dan memberikan penanganan dengan baik. Pelatihan ini bertujuan untuk membekali guru bimbingan konseling melalui pencegahan dan penanganan cyberbullying pada siswa didiknya. Pengabdian Masyarakat ini bekerja sama dengan Musyawarah Guru Bimbingan Konseling se-Jakarta Pusat (MGBK). Peserta pelatihan sebanyak 17 orang guru bimbingan konseling dari berbagai sekolah SMK di Jakarta Pusat. Hasil dari pelatihan ini terlihat bahwa terdapat peningkatan pengetahuan dan keahlian guru terhadap penanganan dan pencegahan cyberbullying berdasarkan hasil pretest dan post test.
\end{abstract}

Kata Kunci : cyberbullying, guru bimbingan konseling, siswa SMA

\section{PENDAHULUAN}

Berbagai tingkat pendidikan saat ini dituntut aktif dalam segi pembelajaran, siswa mengikuti kegiatan pembelajaran dengan pendekatan active leaner. Keterlibatan siswa sebagai pembelajar aktif menuntut siswa untuk mencari sumbersumber pembelajaran melalui internet. Selain penggunaan internet untuk pembelajaran, siswa juga menggunakan media Internet sebagai alat hiburan dan sosialisasi dengan teman sebaya. Berdasarkan data Asosiasi Penyelenggara Jasa 
Internet Indonesia (APJII) penggunaan Internet di Indonesia setiap tahunnya terdapat peningkatan, dari 262 juta penduduk Indonesia 143,26 juta jiwa aktif sebagai pengguna Internet. Mayoritas pengguna juga merupakan mereka yang berusia antara 13 -18 tahun sebesar 75. 5\% (APJII, 2017). Penggunaan Internet yang meningkat dikalangan remaja, tentunya membawa resiko terhadap remaja, salah satunya adalah cyberbullying.

Cyberbullying adalah perilaku intimidasi yang dilakukan oleh seseorang maupun kelompok untuk menghujat dan mencemooh seseorang melalui media telekomunikasi. Pesan yang disampaikan dapat menggunakan telepon, tablet, dan komputer. Pesan dapat berupa pesan singkat, pesan melalui email, blog dan ruang percakapan pribadi maupun online (chatting) (Kowalski, Limber, \& Agatston, 2008). Berdasarkan data Ipsos dari berbagai negara, sejak 2011 terdapat peningkatan laporan dari orang tua yang melaporkan anaknya menjadi korban dalam cyberbullying (www.Ipsos.com). Di Indonesia kasus cyberbullying tidak banyak terungkap, dikarenakan tidak semua korban mau berbicara kepada teman, orang tua ataupun guru. Penelitian yang dilakukan oleh Nursanti (2015) menyatakan bahwa terdapat beragam peran remaja dalam cyberbullying $(n=159)$, diantaranya $32 \%$ remaja pernah berperan sebagai pelaku, $47 \%$ sebagai korban dan $34 \%$ pernah menyaksikan cyberbullying. Berdasarkan penelitian tersebut dapat disimpulkan bahwa remaja yang aktif dalam penggunaan internet memiliki resiko terlibat dalam cyberbullying baik sebagai pelaku, korban, maupun saksi.

Sementara itu cyberbullying memiliki dampak yang buruk bukan hanya kepada korban tapi juga kepada pelaku. Efek yang dapat dihasilkan dari peristiwa cyberbullying adalah korban mengaku merasa sedih, cemas, takut dan tidak dapat berkonsentrasi di sekolahnya (Juvonen \& Gross, 2008), cyberbullying menyakiti perasaan secara psikis dibanding fisik (Huang \& Chou, 2010), korban mengalami permasalahan dalam psiko sosial dan problema kehidupan (Tokunaga, 2010). Menurut Gimenez, Hunter, Durkin, Arnaiz, dan Maquilon, (2015) menyatakan bahwa, terdapat perbedaan dampak emosi antara korban, pelaku, pelaku dan korban. 
Dampak emosi sedih ( $s a d$ ) dan menarik diri (rejected) banyak dialami oleh korban cyberbullying, sementara partisipan yang pernah mengalami sebagai korban-pelaku merasakan sakit hati (offended) dan takut (scared). Korban cyberbullying juga merasakan kesepian (Sahin, 2012). Penelitian yang dilakukan oleh Gradinger, Strohmeier, dan Spiel (2010) menghasilkan bahwa korban yang mengalami keduaduanya (traditional bullying dan cyberbullying) lebih mengalami depresi dan simtom somatic dibandingkan dengan partisipan yang tidak menjadi korban sama sekali. Kowalski, Giumetti, Schroeder, dan Lattanner (2014) korban cyberbullying secara psikologis keadaannya erat dengan stress dan ide untuk bunuh diri.

Cyberbullying dapat terjadi dimana saja dan tidak terbatas hanya disekolah atau dirumah. Namun dampak cyberbullying dapat mempengaruhi performa, perilaku dan pencapaian siswa disekolah. (Bamford, 2005; Wolak, Mitchell \& Finkelhor, 2007) menemukan bahwa siswa yang keluar dari sekolah kebanyakan mereka terlibat dalam cyberbullying. Menurut Li (2006) cyberbullying merupakan permasalahan yang serius dikalangan remaja. (Li, 2006).

Berdasarkan wawancara penyuluh dengan beberapa orang guru di sekolah SMKN Jakarta pusat, mereka menyatakan bahwa "cyberbullying, kerap terjadi" , "cyberbullying dilakukan oleh siswa kepada guru" "cyberbullying terjadi antar siswa" "beberapa anak melaporkan kepada guru bahwa mereka menyaksikan temannya membuli sesama teman atau orang lain yang tidak mereka kenal dimedia sosial", "cyberbullying, terjadi diluar sekolah, kami para guru tidak memiliki cukup data, bukti untuk dapat menindak lanjuti permasalahan ini”

Berdasarkan permasalahan diatas cyberbullying terjadi diluar sekolah disebabkan siswa menggunakan handphone dan akses media sosial diluar sekolah, namun pelaku, korban dan juga saksi adalah merupakan orang-orang disekeliling mereka yang juga beraktifitas disekolah yang sama. Sehingga secara tidak langsung, cyberbullying mempengaruhi kenyamanan dan suasana akademik siswa yang terlibat dalam cyberbullying. Oleh karena itu perlu diadakan penyuluhan dan pemberian informasi yang tepat terhadap guru terkait tindakan dan penanganan cyberbullying 
disekolah. Hal tersebut disebabkan, dampak yang dihasilkan cyberbullying berpengaruh terhadap perilaku anak disekolah.

Pencegahan dan penanganan cyberbullying dapat dimulai dari guru. Keberadaan guru bimbingan konseling disekolah merupakan upaya untuk memberikan pengetahuan, kemampuan yang diharapkan dapat menolong siswa diberbagai bidang baik secara akademik, sosial, dan personal/pribadi,. Berdasarkan deskripsi tugasnya guru bimbingan konseling memiliki waktu yang lebih banyak berinteraksi dengan siswa, dikarenakan, guru-guru bimbingan konseling dituntut untuk dapat menjadi pengajar serta menangani beragam permasalahan yang dialami oleh siswa, maka diperlukannya ketrampilan untuk dapat mengatasi berbagai masalah. Dilain pihak guru bimbingan konseling terkadang memiliki keterbatasan baik pengetahuan maupun ketrampilan dalam menghadapi permasalahan tertentu, sehingga perlunya pelatihan untuk kembali mengasah dan menambah pengetahuannya. Menurut Bhat (2008) guru dan konselor kurang memiliki pengetahuan tentang komunikasi secara elektronik dimana kemampuan tersebut sebenarnya dapat membantu dan mendampingi siswa dalam permasalahan cyberbullying. Pada penyuluhan ini pelaksana berkerjasama dengan Musyawarah Guru Bimbingan Konseling (MGBK) Jakarta Pusat. Pelatihan diharapkan dapat memberi pengetahuan kepada guru bagaimana upaya untuk mencegah dan melakukan tindakan dalam kasus cyberbullying.

Program pengabdian masyarakat ini memiliki tujuan, memberikan penyuluhan dan kesadaran kepada guru bimbingan konseling dalam menghadapi berbagai permasalahan yang terjadi terkait dengan kemajuan teknologi yang dialami oleh siswa, terutama terkait dengan cyberbullying. Memberikan pembekalan pengetahuan dan kemampuan pada guru bimbingan konseling agar dapat menangani permasalahan cyberbullying dengan baik, bertindak aktif dan dapat merespon dengan cepat dan melakukan tindakan yang tepat.

Program pengabdian masyarakat ini memiliki manfaat untuk: Menambah kepedulian guru terhadap permasalahan cyberbullying yang terjadi pada siswa. 
Kepedulian ini terdiri dari sikap responsif terhadap pencegahan dan penanganan. Guru di harapkan memiliki pengetahuan dan kemampuan yang cukup untuk dapat menangani permasalahan dengan lebih baik berdasarkan hasil kegiatan yang telah dilakukan. Guru dapat membantu pihak sekolah untuk merumuskan peraturan dan kebijakan yang terkait dengan penggunaan dan penyimpangan yang terjadi diakibatkan oleh sarana media teknologi telah dilakukan. Guru dapat membantu pihak sekolah untuk merumuskan peraturan dan kebijakan yang terkait dengan penggunaan dan penyimpangan yang terjadi diakibatkan oleh sarana media teknologi.

\section{METODE}

Metode yang digunakan dalam pelatihan ini berbentuk ceramah, pemutaran video, dan tugas kelompok. Pada penyuluhan ini, peserta pelatihan adalah perwakilan Guru Bimbingan Konseling dari berbagai Sekolah Menengah diJakarta Pusat. Mitra Kerjasama adalah Musyawarah Guru Bimbingan Konseling (MGBK) Jakarta Pusat I. Penyuluh membuat modul sebagai panduan dalam pelatihan. Pembuatan modul materi pelatihan tentang pencegahan dan penanganan cyberbullying merujuk pada Kowalski, Limber, dan Agatston (2008) Kegiatan pelatihan dibagi menjadi 3 TAHAPAN. Kegiatan ini dimulai dengan mengidentifikasi pengetahuan peserta pelatihan terkait cyberbullying. Tahapan pretest dilakukan sebagai evaluasi awal untuk mengetahui kemampuan dasar yang dimiliki oleh para guru bimbingan konseling. Tahapan kedua pelatihan berisi materi terkait pencegahan dan penanganan cyberbullying diantaranya adalah ; (a) Mengenal cyberbullying brain awareness, dilakukan bertujuan untuk mengenalkan kepada guru apakah yang dimaksud dengan cyberbullying, dampak yang terjadi Pengenalan ini sangat penting untuk menyamakan persepsi mengenai batas-batas yang dimaksud dengan cyberbullying. Pada sesi ini dilakukan secara interaktif sehingga pemateri juga mendapatkan masukan dari para guru "apakah yang dimaksud dengan cyberbullying" (b) Kegiatan terstruktur yang dapat dilakukan oleh guru dalam pencegahan dan cyberbullying (c) Strategi penanganan cyberbullying disekolah. 
Kemudian, tahapan evaluasi yaitu post test dan pelaksanaan pelatihan. Posttest dilakukan bertujuan untuk mengetahui apakah terdapat peningkatan pengetahuan setelah dilakukan penyuluhan. Pelatihan ini dianggap berhasil jika terdapat peningkatan pengetahuan guru terhadap materi pelatihan. Selain posttest pada tahapan ini penyuluh juga melakukan evaluasi kegiatan PKM. Evaluasi ini bertujuan untuk mengetahui manfaat pelatihan bagi guru bimbingan konseling. Evaluasi dilakukan 1 kali diakhir sessi kegiatan.

\section{HASIL DAN PEMBAHASAN}

Peserta penyuluhan pengabdian kepada Masyarakat ini adalah guru Bimbingan konseling dari SMKN yang berada di Jakarta Pusat, dari 20 undangan yang telah kami sebarkan, terdapat 17 orang guru Bimbingan Konseling yang mengikuti pelatihan yang terdiri dari 5 orang dengan jenis kelamin laki-laki dan 11 orang dengan jenis kelamin perempuan.

Kegiatan ini dimulai dengan melakukan pretest, yang bertujuan untuk melihat tingkat pemahaman yang dimiliki oleh para peserta sebelum penyuluhan. Selanjutnya hasil pretest akan dibandingkan dengan hasil posttest yang didapat setelah mengikuti pelatihan. Hasil pretest dan posttest akan kami bahas kemudian.

Pada Materi pelatihan (a) mengenal cyberbullying. Penyuluh menggali dan menyamakan persepsi mengenai cyberbullying yang mereka ketahui selama ini Beberapa guru mengemukakan bahwa cyberbullying terjadi disekolah mereka. Guru menyatakan bahwa yang dimaksud dengan cyberbullying adalah perilaku bullying yang terjadi di dunia maya dilakukan melalui media sosial dapat berupa pesan singkat, pesan video dan gambar. Pernyataan guru sejalan dengan definisi yang dikemukakan oleh Persamaan persepsi mengenai cyberbullying ini sesuai dengan Notar, Padgett, dan Roden (2013) bahwa strategi untuk mencegah cyberbullying di mulai dengan mendefinisikan bullying dan cyberbullying secara jelas, sehingga sekolah dapat membuat tindakan pencegahan dan penanganan dan menetapkan peraturan dengan baik. 
Pada materi kedua penyuluhan menekankan pada tahapan pencegahan. Pencegahan yang dapat dilakukan oleh guru adalah dengan mengidentifikasi melalui penilaian, membentuk forum pencegahan cyberbullying dan membuat peraturan yang jelas mengenai cyberbullying.

Pada sessi ketiga, Penyuluhan menekankan pada penanganan. Hal-hal yang dapat dilakukan oleh guru adalah (1) Mengamankan bukti terkait dengan cyberbullying, (2) Mengkomunikasikan pelaku jika pelaku merupakan siswa, (3) Legal advice; jika orang tua pelaku tidak merespon dengan baik panggilan dari sekolah dan perilaku tersebut terus berlanjut, maka sekolah dapat meminta bantuan kepada lembaga hukum. (4) law enforcement : dilakukan dengan melaporkan peristiwa cyberbullying kepada pihak yang berwenang. (5) mental support dilakukan ketika terdapat indikasi bahwa siswa melakukan hal yang berbahaya terhadap dirinya, atau pelaku, korban maupun saksi merasa terganggu secara emosi, srta menunjukan gejala psikologis. Pada pelatihan ini menekankan pada bentuk penanganan terkait mental support yaitu fokus terhadap solusi.

Sebelum sessi berakhir para peserta dibagi menjadi 3 kelompok. Masing-masing kelompok diminta untuk mendiskusikan rancangan kegiatan yang dapat dilakukan untuk mencegah dan menangani cyberbullying dengan melibatkan siswa dan orang tua, peserta juga diminta untuk merancang sebuah peraturan sekolah terkait cyberbullying.

\section{Hasil Pretest dan Posttest}

Berdasarkan pernyuluhan yang telah dilakukan, berikut ini adalah hasil evaluasi pretest dan posttest. Terdapat perbedaan yang signifikan antara hasil pretest dan posttest dengan nilai t -5694 (Tabel 1) 
Tabel 1 Paired Samples Test

\begin{tabular}{llrr}
\hline & & \multicolumn{1}{c}{ Pair 1 } \\
& & PRE - POST \\
\hline Paired & Mean & -1.188 \\
\cline { 2 - 4 } Differences & Std. Deviation & .834 \\
\cline { 2 - 4 } & Std. Error Mean & .209 \\
\cline { 2 - 4 } & 95\% Confidence Interval of & Lower & -1.632 \\
\cline { 2 - 4 } & the Difference & -.743 \\
\hline $\mathrm{t}$ & & & -5.694 \\
\hline df & & & 15 \\
\hline Sig. (2-tailed) & & .000 \\
\hline
\end{tabular}

Adapun berdasarkan tabel 2. Terlihat bahwa setiap individu memiliki kesamaan peningkatan pengetahuan dari sebelum dan sesudah pelatihan, dengan demikian dapat dikatatakan bahwa penelitian ini cukup efektif diberikan kepada guru bimbingan konseling

Tabel 2. Paired Samples Correlations

\begin{tabular}{lrr|r|r}
\hline & & $\mathrm{N}$ & Correlation & Sig. \\
\hline Pair 1 & PRE \& POST & 16 & .771 & .000 \\
\hline
\end{tabular}

\section{Hasil Evaluasi Efektifitas Pelatihan}

Pada tabel 2 tampak bahwa peserta pelatihan mendeskripsikan terkait efektifitas pelatihan. Secara umum peserta kegiatan mereasa puas dengan pelatihan yang telah dilakukan, namun peserta merasa kurang puas dengan waktu pelaksanaan kegiatan yang dirasa hanya sebentar. Hal tersebut disebabkan beberapa peserta menyatakan bahwa sebaiknya waktu pelatihan lebih panjang dari yang ada. 
Tabel 3. Efektifitas Pelatihan
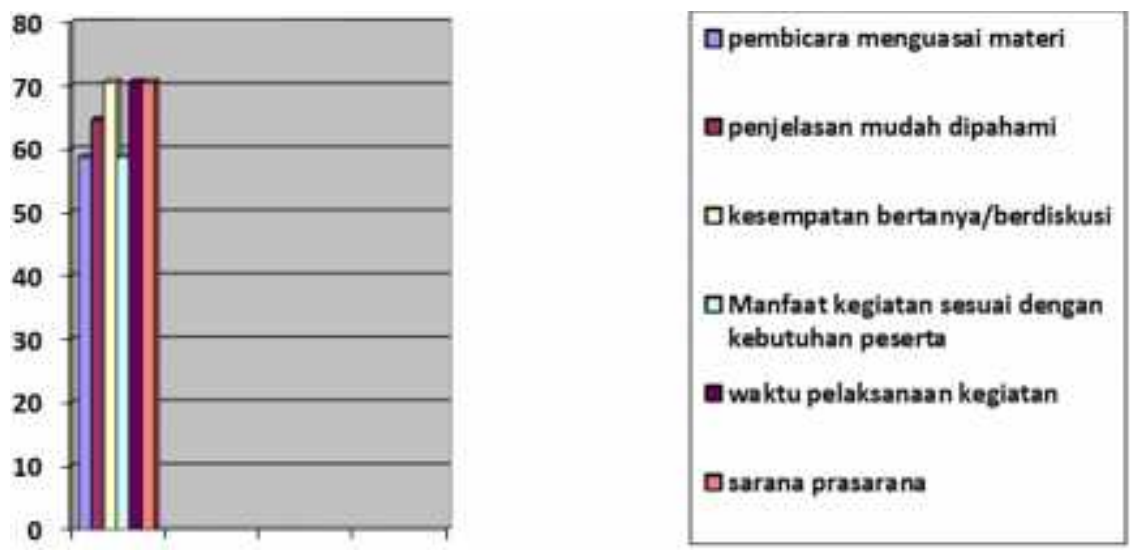

\section{Pembahasan}

Berdasarkan hasil observasi, interaksi selama pelatihan dan penilaian melalui kuesioner terdapat pengaruh yang signifikan peningkatan pengetahuan dari sebelum dan sesudah pelatihan. Selama ini guru mengetahui istilah cyberbullying, namun guru masih belum memiliki benang merah sebatas mana suatu tindakan dimedia sosial disebut sebagai cyberbullying. Guru selama ini juga menyadari bahwa cyberbullying terjadi dikalangan siswa, dan mengganggu performa sekolah siswa. Untuk itu guru, sekolah dan siswa harus memiliki definisi yang jelas mengenai batasan-batasan yang dimaksud cyberbullying.

Selama ini pihak sekolah belum memiliki cara pencegahan dan penanganan yang dapat dilakukan kepada siswa yang terlibat cyberbullying, karena kebanyakan cyberbullying terjadi diluar jam sekolah, sehingga banyak guru yang tidak mengetahui keterlibatan siswa dalam cyberbullying namun dampaknya dirasakan dalam kegiatan akademik siswa. Permasalahan ini disebabkan tidak semua siswa yang menyaksikan cyberbullying mau melaporkan kepada guru maupun orang dewasa lainnya seperti orang tua. Hal ini sejalan dengan Penelitian yang dilakukan oleh Li (2006) bahwa hanya 64\% dari 264 siswa percaya bahwa orang dewasa (orang tua dan guru) dapat bertindak untuk menghentikan cyberbullying. Selain itu, selama ini guru sudah menerapkan beberapa peraturan terkait penggunaan handphone 
disekolah. Penanganan dan pencegahan yang tidak maksimal dapat disebabkan oleh kurangnya pengetahuan guru terhadap isu cyberbullying. Kerjasama dalam penanganan cyberbullying sangat diperlukan bukan hanya terbatas pada guru dan siswa tapi juga dengan orang tua. Sehingga ketika terjadi permasalahan mudah bagi guru untuk mengkomunikasikan kepada orang tua.

Secara umum terkait efektifitas pelatihan peserta menyatakan puas dengan pelatihan ini, saran yang diberikan alokasi waktu pelatihan bisa lebih lama dilakukan.

\section{KESIMPULAN DAN SARAN}

Berdasarkan pemaparan sebelumnya, dapat disimpulkan bahwa cyberbullying menjadi permasalahan yang terjadi dikalangan siswa. Pelatihan ini efektif dan dapat memenuhi kebutuhan guru-guru bimbingan konseling dalam mencegah dan menangani perilaku cyberbullying. Pengabdian masyarakat ini dapat menjadi acuan akan kebutuhan peraturan tertulis disetiap sekolah dalam penanganan terkait isu-isu cyberbullying.

Pihak Sekolah dan orang tua harus bekerja sama dalam upaya penanganan dan pencegahan cyberbullying. Sekolah dapat merancang peraturan dan prosedur penanganan cyberbullying. Sekolah dapat membuat kegiatan yang melibatkan siswa terkait isu-isu cyberbullying dan penggunaan internet sehat.

\section{DAFTAR PUSTAKA}

APJII (2017). Hasil Survei Penetrasi dan Perilaku Pengguna Internet Indonesia. Diunduh dari https://apjii.or.id/survei.

Bamford, A. (2005). Cyber-bullying. Classroom, 25(1), 18-19.

Bhat, C. S. (2008) Cyber Bullying: Overview and Strategies for School Counsellors, Guidance Officers, and All School Personnel. Australian Journal of Guidance \& Counselling, 18 (1), 53-66. 
Beran, T., \& Li, Q. (2005). Cyber-harassment: a study of a new method for an old behavior. Journal of Educational Computing Research, 32(3), 265-277. doi:10.2190/8YQM-B04H-PG4D-BLLH.

Gradinger, P., Strohmeier, D., \& Spiel, C. (2010). Definition and Measurement of Cyberbullying. Cyberpsychology: Journal of Psychosocial Research on Cyberspace, 4(2), article 1. Retrieved from https://cyberpsychology.eu/article/view/4235

Gualdo, A.G., Hunter, S.C., Durkin, K., Arnaiz, P., Maquilon, J. J., (2015). The emotional impact of cyberbullying: Differences in perceptions and experiences as a function of role. Computer and Education. 82. 228235. Available

from https://www.researchgate.net/publication/269728645_The_emotional_i mpact_of_cyberbullying_Differences_in_perceptions_and_experiences _as_a_function_of_role [accessed Jul 15 2019].

Hazelden, (2008). Cyberbullying: A Prevention Curriculum for Grades 6-12 Scope and Sequence. Diunduh dari www.hazelden.org/cyberbullying.

Huang, Y., \& Chou, C. (2010). An analysis of multiple factors of cyberbullying among junior high school students in Taiwan. Computers in Human Behavior, 26(6), 1581-1590

Juvonen, J. \& Gross, E. F. (2008). Extending the School Grounds?-Bullying Experiences in Cyberspace. Journal of School Health, 78 (9), 496-505

Kowalski, R.M.,Giumetti, G.W.,Schroeder, A. N., Lattanner, M.R. (2014). Bullying in the digital age: A critical review and meta-analysis of cyberbullying research among youth. Psychological Bulletin, 140(4), 1073-1137.

Kowalski, R. M., Limber, S. P., \& Agatston, P.W. (2008). Cyberbullying: Bullying in the Digital Age. Singapore: Blackwell Publishing

Li, Q. (2006). Cyberbullying in schools: A research of gender differences. School Psychology International, 27(2), 157-170. doi:10.1177/0143034306064547.

Li, Q. (2007). Bullying in the new playground: Research into cyberbullying and cyber victimisation. Australasian Journal of Educational Technology, 23(4), 435-454. 
Notar, C. E., Padgett, S., \& Roden, J. (2013). Cyberbullying: Resources for Intervention and Prevention. Universal Journal of educational Research, 1(3), 133-145. DOI: 10.13189/ujer.2013.010301.

Nursanti, A. (2015). Gambaran Perilaku Cyberbullying pada Siswa Sekolah Menengah Atas DKI Jakarta. Jurnal Psikogenesis, 3(2), 116-222.

Patchin, J.W. \& Hinduja, S. (2012). Cyberbullying Prevention and Response: Expert perspectives. NewYork: Routledge.

Şahin, M. (2012). The relationship between the cyberbullying/cybervictmization and loneliness among adolescents. Children and Youth Services Review, $34,834-837$

Tokunaga, R.S. (2010). Following you home from school: A critical review and synthesis of research on cyberbullying victimization. Computers in Human Behavior, 26(3), 277-287. doi:10.1016/j.chb.2009.11.014.

Wolak, J., Mitchell, K. J., \& Finkelhor, D. (2007). Does Online Harassment Constitute Bullying? An Exploration of Online Harassment by Known Peers and Online-Only Contacts. Journal of Adolescent Health, 41, 5158. https://doi.org/10.1016/j.jadohealth.2007.019 